\title{
Reklamesemiotik mellem mening og virkning - komposition, kategorier og kognition
}

\author{
Af Christian Andersen \& Christian Jantzen
}

\begin{abstract}
På baggrund af kognitionspsykologi og peirceansk tegnteori fremsetter artiklen et reklamesemiotisk bud på sammenhangen mellem annoncers komposition og deres virkning. Artiklen har til formål at belyse, hvorledes den trykte annonces forskellige astetikker og kompositioner udløser forskellige emotionelle og kognitive effekter i receptionen. Der indkredses tre receptionsmodi, der hver svarer til en bestemt annoncekompositorisk kategori. Artiklen er en videreudvikling af reklamesemiotikken, som i Danmark iser er blevet funderet på et semiologisk grundlag. Der argumenteres for, at den semiologiske tilgang kun er delvis fyldestgørende, eftersom man her laser reklamens illustration med verbalsproget som model og derved implicit antager, at verbalsproglige og visuelle tegnsystemer har samme organisation. I modsatning til sproget mangler billedet imidlertid den dobbelte artikulation. Artiklen forsoger at indfange disse forskelle mellem tegnsystemer for derigennem at oparbejde et mere nuanceret blik for, i hvilket omfang forskellige reklameastetikker faktisk udloser bestemte kognitive effekter i receptionen. Ved 'kognitive effekter' forstås primart emotionsdannelse og inferensprocesser.
\end{abstract}

I videre forstand kan kognitionspsykologi og peirceansk semiotik levere en holistisk ramme, inden for hvilken det kan beskrives, hvorledes opmærksomhed, tænkning, hukommelse, emotion og handling funktionelt hænger sammen i forbindelse med reklamens generelle betydningsdannelse. Da artiklens formål er at tematisere forholdet mellem reklameæstetik og kognition, er den overordnet tænkt som et bidrag både til den effektforskning, som foregår indenfor marketing $o g$ forbrugeradfærdsteorien og til den forskning $i$ reception og medieæstetik, som foregår i medievidenskaben. Med hensyn til receptionsforskningen påpeges nødvendigheden af at udvide spektret af undersøgelsesmetoder og teoretiske tilgange (receptionsæstetik, kognitionsteori), hvis man skal nå frem til en realistisk beskrivelse af receptionsprocesserne i modtagelsesøjeblikket.

\section{Reklame og semiotik}

Reklameforskning var længe handelshøjskolernes eksklusive domæne. Her blev erfaringer fra marken systematiseret og kombineret med diverse indsigter og antagelser fra i særdeleshed psykologien.
Dette hedder marketingteori og forbrugerteori (consumer research) og har et decideret praktisk sigte. Indtil 1980 var området baseret på en ad åre modificeret udgave af behaviorismen især med fokus på købsbeslutningen hos den individuelle forbruger, der oprindeligt blev opfattet som et pavlovsk dyr og senere som en rationel beslutningstager. Feltet hed derfor længe consumer behaviour. Dette paradigme sprænges dog efter 1980, idet hidtil oversete aspekter ved beslutningsprocessen kommer i fokus: nemlig betydningen af budskabets æstetiske udformning, 'irrationelle' momenter i beslutningsprocessen samt forbrugets sociale kontekst som en faktor ved købet. ${ }^{1}$ Handelshøjskolerne får blik for andre grundvidenskaber, og der ansættes folk med tekstvidenskabelig og sociologisk eller antropologisk baggrund. Og på det tekstvidenskabelige område er det ikke mindst semiotikken, der i første omgang tager kegler. Både i dansk og international sammenhæng bliver forskningsfeltet 'Marketing \& Semiotik' trendy på de erhvervsøkonomiske studier omkring 1985. ${ }^{2}$ Dette forskningsfelt har imidlertid ikke formået at slå rødder i Handelshøjskolemiljøet, hverken nationalt eller internationalt. 
I de ti år, hvor reklamesemiotikken blomstrede, var Danmark godt repræsenteret. Det skyldtes, at man havde en række tekstvidenskabelige forskere, der var dygtige til at omsætte deres kunnen til anvendelige resultater. Og det skyldtes fremdeles, at der i Danmark allerede fandtes en tradition for at beskæftige sig semiotisk med reklamer. Denne tradition trivedes på de humanistiske fakulteter, var af semiologisk observans, og udsprang af 1970'ernes litteraturvidenskabelige interesse for popkulturens tekster. Det 'udvidede tekstbegreb' bragte ikke mindst reklamen i fokus, som blev analyseret semiotisk, om end oftest i en light-udgave, med henblik på at afdække de ideologiske eller driftsmæssige mønstre, som annoncen udsprang af og samtidig havde til formål at befæstne yderligere. Reklamer blev analyseret som symptomer på en underliggende struktur af samfundsmæssig og/eller psykoanalytisk karakter, som var det egentlige forskningsobjekt.

Set fra et overordnet perspektiv havde denne reklamesemiotik altså det teoretiske og metodiske grundlag - nemlig semiologien - til fælles med de reklameanalyser, der var blevet dyrket på Humaniora siden 1970'erne. Til gengæld havde reklamesemiotikken ingen berøringsangst over for den empiriske virkelighed og over for det erhvervsliv og den kommercielle interesse, som reklamer jo udspringer af. Reklamesemiotikken var frugtbar, netop fordi den også reelt forsøgte at sammentænke marketingdiciplinen med semiotikken. Desuden stillede den skarpt på den underliggende antagelse, som havde båret 1970'ernes reklameanalyser: nemlig at reklamer udspringer af samfundsmæssige forhold, og at de påvirker - bekræfter, befæstner - samfundsmæssige magtforhold. Reklamesemiotikken havde i den forstand tillige et kulturanalytisk sigte, idet den ville udforske, hvordan reklameteksten og den sociokulturelle kontekst faktisk vekselvirker med hinanden. ${ }^{3}$ I forhold til 1970'ernes reklameanalyser udfoldede reklamesemiotikken et mere nuanceret perspektiv på samspillet mellem reklame og kultur, idet den betonede vekselvirkningen mellem æstetisk struktur, genreforhold og intertekstualitet på den ene side og kodekompetencer, mediemæssige vilkår og positioneringsbestræbelser på den anden. På dette punkt var reklamesemiotikken helt på bølgelængde med 1980'ernes store nybrud i dansk medieforskning, nemlig receptionsteorien og medieetnografien, der rettede blikket mod, hvad og hvordan modtagere faktisk bruger mediebudskaber. Denne brug blev dog fortrinsvis relateret til modtagerens sociokulturelle livsverden.

At reklamesemiotikken sygnede hen fra midten af 1990'erne skyldes ikke mindst institutionsmæssige forhold, som fik en del af forskerne til at forlade læreanstalterne. ${ }^{4}$ Men det er vores tese, at dette forfald også hænger sammen med det paradigme, som reklamesemiotikken byggede på. Ved at være semiologisk i sit udgangspunkt og ved primært at være kulturalistisk i sin erkendeinteresse nåede den kun at udforske delaspekter ved tegndannelsen i reklamen. ${ }^{5}$ Det er nemlig iøjnefaldende, at den reklamesemiotiske tilgang var god til at forbinde æstetik med marketing og med det sociokulturelle område, men at den samtidig syntes at afgrænse sig mod det psykologiske område, som ellers hidtil havde været forbrugerteoriens fundament. Dette havde f.eks. som konsekvens, at reklamesemiotikken ikke formåede at bidrage til videreudviklingen af effektforskningen, et kardinalpunkt i forbrugerteorien. Ligeledes forblev de kognitive faktorer ved modtagelsen og brugen af reklamer ubelyst, da al interesse i stedet samlede sig om kulturelle faktorer. Og slutteligt blev sammenhængen mellem reklamens æstetik og dens evne til at skabe opmærksomhed ikke udviklet tilstrækkeligt, fordi samspillet mellem perception og betydningsdannelse forblev utematiseret.

Vi vil derfor i denne artikel plædere for et nyt reklamesemiotisk paradigme, der hviler på et peirceansk grundlag. Da et sådant udgangspunkt er i stand til at indtænke kognitions- og perceptionspsykologiske aspekter, kan dette paradigme i langt højere grad end det semiologisk baserede belyse sammenhængen mellem reklamers æstetik og tænkningens og emotionernes domæne. Vi vil i det efterfølgende forsøge at vise, hvorledes en peirceansk reklamesemiotik kan bidrage til en af forbrugerteoriens centrale problemstillinger, nemlig sammenhængen mellem æstetik og effekt. Men først vil vi mere overordnet påpege problemerne ved den semiologiske reklamesemiotik for dermed at aftegne det bredere felt, som en peirceansk reklamesemiotik med udbytte kan anvendes inden for.

\section{Det lingvistiske paradigme: karakteristik og kritik}

Den semiologisk baserede reklamesemiotik bygger væsentligst på en enkel og forholdsvis kort 
tekst, som endda kun bruger reklamen som en anledning til at anskueliggøre billedsemiologiens ærinde, nemlig Roland Barthes' "Billedets retorik" fra 1964. Artiklen er interessant allerede af den grund, at den på trods af titlen ikke forsøger at udvikle en egentlig visuel semiotik. Til gengæld er teksten en af de klareste manifestationer af 'den lingvistiske drejning' inden for humanvidenskaberne i 1960'erne, hvilket måske er den væsentligste årsag til tekstens store udbredelse og fortsatte popularitet. Barthes underordner nemlig metateoretisk semiologien under lingvistikken, som således bliver gjort til modelvidenskab. ${ }^{6}$ Artiklens pædagogiske force er da også, at begreber fra sprogvidenskaben bruges til at beskrive reklamebilledet med. Det gælder ikke mindst begreber som denotation og konnotation. Dermed får Barthes udviklet et begrebsapparat, der muliggør en tekstvidenskabelig beskrivelse, analyse og fortolkning af billedet.

Problemet ved dette begrebslån er blot, at det er aldeles usemiotisk tænkt. Lingvistiske termer kan ikke uden videre appliceres på billeder af den simple grund, at det visuelle tegnsystem er af en hel anden beskaffenhed end sprogsystemet. Til forskel fra sprogsystemet mangler de visuelle tegn den dobbelte artikulation. De er betydningsbærende men ikke betydningsadskillende. Dette problem viser sig også direkte i Barthes egen tekst. Han bliver nødt til at bøje konnotations- og denotationsbegrebet så meget for at kunne anvende det på billedets tegn, at begreberne bliver selvmodsigende. ${ }^{7}$ De bøjes simpelthen ad led. På den måde er forsøget på at opbygge en konsistent fagterminologi allerede fra starten kuldsejlet. Desuden er det slående, at Barthes går uden om en principiel diskussion af forskellen mellem sprog og billeder, når det gælder disse tegnsystemers funktion og pragmatiske effekt. Sprogtegnet er på det punkt kendetegnet ved at egne sig til begrebsdannelse. Det kan udpege og uddybe, altså definere og præcisere. Omvendt har billedtegnet den egenskab, at det kan fremvise, men ikke udpege. Det egner sig ikke til begrebsdannelse men derimod til stemningsskabelse. Billedet kan være suggestivt og umiddelbart sanseligt på en måde, som sproget højest kan forsøge at efterligne (f.eks. i billedsproget eller i lydbilledet). Billedet er ikonisk, hvorimod sproget er symbolsk (konventionelt) og kan bruges indeksikalsk. Denne forskel tematiserer Barthes kun indirekte, nemlig ved det begrebspar, som utvivlsomt er artiklens mest frugtbare bidrag: afløsning og forankring. Begrebsparret betegner to forskellige måder, som den sproglige tekst kan forvalte sin indeksikalitet i forhold til billedet på. Forankring står for tekstens evne til at udpege og forklare billedets væsentlige information, hvorimod afløsning skaber ny og supplerende information i forhold til billedets mening. Selve begrebsparret udstanser hele Barthes' ærinde: nemlig at undersøge, hvad sproget gør i forhold til billedet. ${ }^{8}$

Konsekvensen af Barthes' lingvisticisme er således, at helt fundamentale forhold ved billedet - og dermed ved (billed)reklamen - overses eller endda fejlforstås. Visualitet behandles ikke på sine egne præmisser, men blot i analogi til sproget. Billedets ikonicitet får derved lov til at ligge hen til fordel for en raffineret tekstanalyse af reklamens skjulte intention. Barthes analyserer én reklame, og det er ikke så få intenderede meninger af især konnotativ karakter, han formår at fremdrage. Dermed demonstrerer han den semiologiske metodes force: ved hjælp af et intrikat begrebsapparat afsløres en dybere hensigt med budskabet, som ikke umiddelbart er synlig for lægfolk. At begrebsapparatet er inkonsistent, betyder i den sammenhæng mindre, da analysens gyldighed beror på analytikerens evne til at sætte ord på det latente bagved det manifeste - eller rettere: på evnen til at overbevise om denne evne, altså på autoritet.

Barthes praktiserer her den form for 'mesterlæsning', som blev modelskabende for 1970'ernes livtag med reklamer og andre typer populære tekster. Erindet blev at sprogliggøre den sandhed, der strukturerede budskabets mening under den tilsyneladende harmløse overflade. Denne ideologikritik udfoldede sig som en indholdsanalyse med udgangspunkt i de sociokulturelt betingede og intersubjektivt forankrede medbetydninger (konnotationer), der blev fortolket som adgangsbilletten til en underliggende tematik. Analytikerens dygtighed beroede så på evnen til at finde de 'rigtige' konnotationskæder. Dette betød reelt en interesseforskydning fra semiologiens og strukturalismens udforskning af universelle strukturer i betydningsdannelsen til kulturafhængige og dermed relative associationsmønstre. $^{9}$ Den semiologiske praksis var blevet kulturalistisk! Epistemologisk set er det noget rod, men i poststrukturalismens æra var det ikke noget problem.

Barthes' banebrydende artikel skabte således 
et lingvistisk paradigme for reklameanalysen, der var kendetegnet ved følgende fem træk:

1) analysen bygger på den antagelse, at hele reklamebudskabet kan analyseres på sprogtegnets præmisser;

2) analysen sigter mod at afdække den latente sandhed, som producerer manifeste betydninger på overfladen;

3) der er tale om indholdsanalyse: dvs. udredning af især konnoteret betydningsindhold med henblik på afdækning af dybere tematiske strukturer;

4) interessen gælder den intenderede mening med teksten, som er tilgængelig via en tekstanalyse (foretaget bag skrivebordet);

5) denne mening er kulturelt funderet og intersubjektivt forankret.

Man kan også sige det på følgende måde: de semiologiske reklameanalyser misforstår det visuelle tegns særlige karakteristika (nemlig ikonicitet), overser den umiddelbare effekt som helheden har (det manifeste), glemmer formens (og dermed æstetikkens) funktion, og ignorerer, hvordan reklamen faktisk opleves, bruges eller virker i real life. Desuden tenderer alle betydninger til at blive et spørgsmål om kultur, hvorved almenmenneskelige principper for perception, kognition og emotion negligeres.

\section{Fra semiologi til reklamesemiotik}

Den semiologisk funderede reklamesemiotik har rettet op på en række af disse skavanker. Man begynder at spørge til, hvad bestemte reklamebudskaber faktisk betyder for folk. Dermed bliver betydning noget andet end den intenderede mening, som kun var tilgængelig for analytikerens øvede blik. Man undersøger endvidere reklamens komposition (syntaks) og dens måde at henvende sig på (pragmatik). Dermed bliver betydning noget andet og mere end blot indhold (semantik). Æstetikken kommer i fokus, og ad åre undersøges den ud fra et relativt stort empirisk materiale. Man analyserer desuden ikke længere blot den enkelte reklames mening, men stræber derimod efter en overordnet klassifikation af reklamens genrer og typer. Dermed bliver det muligt at fremsætte bud på udtrykkets æstetiske potentialer. ${ }^{10}$
Alligevel forblev reklamesemiotikken på afgørende punkter inden for det lingvistiske paradigme og arvede således nogle af dets problemer. I og med at sprogets primat forblev uantastet, har heller ikke reklamesemiotikken været i stand til at udvikle eller bidrage til en egentlig visuel semiotik. Reklamens ikonicitet er fortsat underudforsket, ${ }^{11}$ bl.a. fordi reklamesemiotikken har haft en tendens til at rette sig mod kompositionens enkeltdele frem for mod det umiddelbare helhedsindtryk, som møder modtageren ved første øjekast. Man har f.eks. interesseret sig for det som regel komplekse samspil mellem reklamens forskellige tekstdele og tegnsystemer for at beskrive, hvorledes reklamens ofte flertydige betydning konstrueres i løbet af receptionen. ${ }^{12}$ Men dermed har man haft en tendens til at se bort fra modtagelsens konkrete sansning og fra de kognitive processer, som modtagelsen gennemløber.

\section{Den reklamesemiotiske receptionsanalyse}

Reklamesemiotikkens indtog på handelshøjskolerne i 1980'erne var i dansk sammenhæng ikke mindst båret af en receptionsanalytisk vinkel på reklame. Hidtil havde markedskommunikationsforskere især beskæftiget sig med de faktorer ved budskabets tilrettelæggelse og kommunikationsprocessens forløb, der hindrer eller fremmer virkningen hos modtageren (f.eks. Ottesen, 1985). Man havde ikke interesseret sig synderligt for budskabets komposition og dets betydning. Og for så vidt modtageren var blevet undersøgt, var det sket på enten kvantitativ eller eksperimentel basis. Tilgangsvinklen var i stedet baseret på afsenderens problemstillinger i forhold til kommunikationsprocessen: hvordan når jeg billigst og hurtigst muligt ud til flest mulige med bedst mulig effekt.

Reklamesemiotikerne kom til de danske handelshøjskoler med en helt anden baggrund end den merkantile, nemlig en tekstanalytisk orienteret medievidenskabelig tilgang. De havde det store, nye dyr i åbenbaringen - receptionsanalysen - med sig og kunne derfor præsentere en helt ny indfaldsvinkel til kommunikationsprocessen. De fæstnede blikket ved de forhold, som hidtil havde unddraget sig opmærksomhed: reklamens komposition og - ikke mindst - modtagerens brug af budskabet. Især Buhl (1989, 1991) var ikke bleg for at understrege, hvor fladpandet og forfejlet 
den hidtidige markedskommunikative tilgang - og for den sags skyld også medievidenskabens gamle garde (ideologikritikerne) - var. Det var ikke populært alle steder, men det var bestemt forfriskende.

Buhls metode og betragtningsmåde er eksemplarisk for den tidlige receptionsforskning i Danmark (Schrøder, 2000). Buhl slår de markedskommunikative og ideologikritiske traditioner i hartkorn og kritiserer dem for at bygge på "kanyleteorien". De fokuserer begge enøjet på, hvad budskabet gør ved modtageren og antager, at den veltilrettelagte påvirkning vitterligt får den tilsigtede effekt hos modtageren. Buhls egen forskningsinteresse er derimod den stik modsatte. Han vil undersøge, hvad modtageren gør ved budskabet. Buhl metodiske design er ganske enkelt: han præsenterer en udvalgt reklame for et fåtal respondenter og beder dem om at fortælle, hvad de forstår ved annoncen. Resultaterne er afsvalende i forhold til ideologikritikkens hede drømme om massiv manipulation og nedtrykkende for den konstruktive marketingforsker: de meninger og vurderinger, som modtagerne hver især fremsætter, er netop meget forskellige. Enhver frygt for eller håb om massepåvirkning smuldrer, da Buhls undersøgelse synes at antyde, at konkrete annoncer læses ud fra modtagernes egne dagsordner, livssituationer og forventningshorisonter, som er rodfæstet i både sociale og individualpsykologiske forhold. Annoncernes polysemi gør, at hver trykt annonce bliver til en mangfoldighed af mulige annoncer, når den betragtes fra modtagerens ståsted. I stedet for veltilrettelagt påvirkning fører afkodningsprocessen til "a complexity close to a chaotic state" (Buhl, 1991, s. 119). Buhl tangerer således Fish' radikale position (1980), der frakender tekster enhver stabil betydning.

Set i bakspejlet er svaghederne ved Buhls tilgang indlysende. Antallet af respondenter er yderst begrænset og således næppe repræsentativt. ${ }^{13}$ Desuden har designet den svaghed, at respondenterne bliver bedt om at forklare og uddybe forhold ved en annonce, som er udvalgt af intervieweren. Meningsarbejdet ledes på vej af de spørgsmål, som intervieweren stiller. Dette antaster undersøgelsens validitet: hvad ville annoncen egentlig have betydet for respondenten, hvis ikke han/hun havde fået den forelagt i en arrangeret mediebrugssituation, var blevet bedt om at mene noget om annoncen og ydermere indbudt til at begrunde og uddybe denne mening? ${ }^{14}$ Slutteligt kan man indvende, at undersøgelsen hviler på en art cirkelslutning: annoncens meninger viser sig at være flertydige - for ikke at sige kaotiske - og dette begrundes med, at kompositionen er polysemisk. Med lidt ond vilje kunne man hævde, at årsag og virkning hos Buhl er identiske. Hvor om alting er, så bliver de æstetiske forhold ved polysemien ikke undersøgt nærmere med det resultat, at kompositionen bliver et faktotum.

Buhl var en af tidens førende receptionsforskere, ikke blot i de mere snævre reklameanalytiske kredse, men i dansk medievidenskab overhovedet. De problemer, som præger hans undersøgelse, er således generelle for en stor del af den tidlige receptionsforskning i Danmark. I forlængelse af vores kritik af lingvisticismen i dansk reklamesemiotik, må man sige, at vores indvendinger også kan udbredes til en stor del af receptionsforskningens tradition. Her har man nemlig for det forste fortrinsvis spurgt respondenter om at verbalisere deres indtryk, oplevelser og sansninger. For det andet har man fokuseret på de kulturbetingede og -skabende aspekter ved mediemodtagelsen. Det vil sige, at det er udtrykkets grad af konventionalitet, som man har forsket i, og netop ikke i de kognitivt betingede faktorer, som fremdeles er knyttet til billedets ikonicitet. Set i forhold til Peirces anden trikotomi har man interesseret sig for medietekstens symbolicitet og for sprogtegnets indeksikalitet. Og det har især været relationen mellem repræsentamen og interpretant i Peirces første trikotomi, der har været fokus på. Forholdet mellem repræsentamen og objekt er til gengæld blevet overset, netop fordi ikoniciteten ikke er blevet gjort til tema. For at spidsformulere vores indvending, så har receptionsforskningen især udforsket modtagelsens situationelle kontekst, som medietekster bruges i, og som præger modtagerens forforståelse. Man har fokuseret på, hvad der sker omkring interaktionen mellem modtageren og tekstens æstetiske komposition. Selve modtagelsesøjeblikket, dvs. de betydningsdannelsesprocesser, der sker $i$ interaktionen, har man overset. Men det er da heller ikke noget, man ubesværet kan sporge meningsfuldt til.

Hvad reklamesemiotikken angår, så har den skabt nyttige indsigter i de æstetiske muligheder, som reklamebranchen har til rådighed. Og den har også dokumenteret, at der kan være mange forståelser af hvert enkelt budskab. Men den er ik- 
ke kommet nærmere en forklaring på den virkning (og ikke mening), som interaktionen mellem budskab og modtager har. Hvis reklamesemiotikken skal være relevant i forhold til forbrugerteorien, som jo netop kredser omkring beslutningsprocesser, skal dette forhold mellem æstetik på den ene side og følelser, tænkning og handling på den anden, udfoldes. Dette kræver et paradigmatisk skift til kognitionspsykologien. Et skift, som den peirceanske semiotik, af grunde som vi vil redegøre for i næste afsnit, er bedre gearet til end semiologien.

I modsætning til hovedstrømmen i dansk receptionsforskning vil vi forsøge at holde fokus på selve modtagelsesøjeblikket. Vores interesse gælder endvidere hverken beskrivelsen af mediebrugens etnografi eller udforskningen af meningsdannelsens horisont. Ærindet er at give et peirceansk bidrag på kognitivt grundlag for at videreudvikle den reklamekategorisering, som den semiologiske tradition har påbegyndt. Vi begrænser os til de trykte annoncer. Vi knytter på sin vis an til det andet vigtige bidrag, som danske reklamesemiotikere leverede til markedskommunikationen, ved at tage udgangspunkt i den semiologisk baserede kategorisering af kompositoriske forhold, som især en anden prominent dansk reklamesemiotiker, Christian Alsted, har foretaget. ${ }^{15}$ Pointen er at vise, hvordan det kognitive paradigme kan skabe ny indsigt i måden, hvorpå kompositionsmæssige forskelle via den kognitive bearbejdning betinger forskelle i receptionsmodi.

\section{Det kognitive paradigme: baggrund og hensigt}

Kognitionsteori er samlebetegnelsen for en tværvidenskabelig forskning, hvis overordnede ærinde er at belyse, hvorledes mennesker tilegner, opbevarer, transformerer, anvender og kommunikerer information. Således beskæftiger kognitionsteorien sig med følgende områder:

- hvorledes sanserne giver os adgang til information fra den omkringliggende verden,

- hvordan denne information organiseres og bearbejdes i vores hjerner.

- hvorledes denne sansede information opbevares og hentes i hukommelsen,

- hvorledes den organiseres i tænkningsprocessen,

- hvorledes den kommunikeres socialt via sproget.
Helt centralt for kognitionsforskningen står derfor en beskrivelse af forholdet mellem sansning, tænkning og sprog.

En vigtig antagelse inden for aktuel kognitionsteori er, at den menneskelige hjernes sanse- og tænkeprocesser bringes i bevægelse af organiske enheder, som er programmeret på forhånd. Disse enheders aktivitet og vækst beror på ydre påvirkning, men deres funktion må i princippet betegnes som autonom. I det perspektiv må væsentlige kognitive processer opfattes som sproguafhængige processer med universel status. Organiseringen af lingvistiske repræsentationer opfattes som forankret i det senso-motoriske systems naturlige struktur (jf. Lakoff, 1987).

Forestillingen om, at sproget er en udbygning af bagvedliggende og universelle kognitive tankestrukturer, kan genfindes inden for den ligeledes realistisk baserede peirceanske semiotik. Centralt for den peirceanske semiotik står den opfattelse, at tænkningsprocessen kommer i stand ved en kompliceret produktion og manipulation af tegn, $\mathrm{og}$ at kognition overhovedet er afhængig af tegn. Vigtige grundtegn inden for Peirces semiotik er ikon, indeks og symbol. Disse tegn adskiller sig fra hinanden ved at have forskellige kodning $\mathrm{i}$ forhold til perception og sprog såvel som til emotionen og repræsenterer således også forskellige grader af universalitet. I det perspektiv kan man sagtens forestille sig en semiotisk indfaldsvinkel til det kognitive område, hvis hovedærinde er undersøgelsen af tænkningens, herunder emotionens, generelle mulighedsbetingelser. En sådan indfaldsvinkel vil være det samme som at opfatte kognitionsforskning som en meta-semiotisk aktivitet. ${ }^{16}$

Derfor plæderer vi i denne artikel for kognitionsteori og semiotik på bekostning af den lingvistiske reklametradition: Reklamer er nemlig i udgangspunktet bestemt til at afsætte en effekt i recipientens krop og hjerne. Og med en sammentænkning af kognitionsteori og semiotik opstår en solid platform til begribelse af hjernens universelle funktionsmåder, udfra hvilken reklamens forskellige elementære kognitive effekter kan forstås. Det menneskelige emotionelle og kognitive system er grundet på medfødte kompetencer. Dertil kommer, at receptionen og afsendelsen af reklamens grundlæggende ikke-lingvistiske emotionelle udtryk - eksempelvis ansigtsmimik og kropspositur - er funderet på nedarvede kompetencer og anlæg. Det er disse kompetencer og anlæg, som 
overhovedet muliggør, at reklamen kan formidle universelle emotioner. ${ }^{17}$

\section{Kategorisering i den semiologiske tradition}

Reklamesemiotikken har som sagt leveret vigtige bidrag i forbindelse med kategoriseringen af reklamens udformning. Formålet har været at lave typologier over de systematiske æstetiske forskelle i reklamers måde at henvende sig til modtageren på. For de trykte annoncers vedkommende har den typologi, som Christian Alsted udviklede i anden halvdel af 1980'erne været banebrydende. Den er afrapporteret i sin endelige form i Alsted \& Hartvig-Larsen "Towards a Semiotic Typology of Advertising Forms" (1991).

I denne artikel præsenteres en kategoriseringsmodel med fire reklametyper: en simpel, en sammensat, en kompleks og en sofistikeret. Kategoriseringen bygger på en beskrivelse af samspillet mellem den enkelte reklames betydningsfelter: illustrationen, overskriften, annonceteksten, signaturteksten (mærkets eller producentens logo) og prisen. Desuden afgør tegnenes repræsentationsmåde typologiseringen. Det er især en integreret dialektik af nærvær og fravær mellem de respektive betydningsfelter inden for den givne komposition, der afgør, hvilken kategori annoncen tilhører. Den simple, sammensatte og komplekse billedreklame har det til fælles, at overskrift såvel som illustration og annoncetekst er present til stede i den samlede komposition. Mens det for den sofistikerede gælder, at kun overskrift og illustration er present til stede i den samlede komposition. Annonceteksten derimod er fraværende. Reklamer i denne kategori forlader sig på illustrationens ofte subtile betydninger. De faktuelle oplysninger, som annonceteksten kan bidrage med, ville snarere forvirre end oplyse. Dette skyldes fremdeles, at kodningen af overskrift og illustration i den komplekse og sofistikerede i høj grad er konnotativ og mytisk. Fælles for den simple og sammensatte annonces overskrift og illustration er derimod, at kodningen er denotativ, og at annonceteksten formidler væsentlig information om produktet. ${ }^{18}$

Alsted \& Hartvig Larsens typologi trækker eksplicit veksler på Barthes' artikel. Den har da også den svaghed, at illustrationens visualitet kun kan behandles i lingvistiske termer (denotation/konnotation). Derfor kan forfatterne kun postuleret analysere mere sofistikerede annoncers illustration og den elementære og primitive kognition, som udløses under receptionen af denne. Alligevel må denne typologi roses for dens evne til at klarlægge grundformerne i den æstetiske og kompositoriske organisering af trykte annoncer. Forholdet mellem betydningsfelterne for annoncens samlede helhedsindtryk spiller nemlig en afgørende rolle for budskabets reception.

\section{Bottom up/top down - bearbejdningen af billede og tekst}

Af Alsted \& Hartvig-Larsens typologi fremgår det, at jo simplere reklamekategorien er, desto mere dominerende er teksten for reklamens generelle betydningsdannelse. ${ }^{19} \mathrm{Og}$ de viser omvendt, at jo mere avanceret reklamekategorien er, desto mere dominerende er billedet for dens generelle betydningsdannelse. Afhængig af hvilken reklamekategori vi har med at gøre, repræsenteres derfor et særligt fordelingsforhold mellem visuelle og tekstlige stimuli, som påvirker os kropsligt og emotionelt, og som forplanter sig forskelligt i det kognitive apparat.

Med et begrebspar hentet fra den perceptionsorienterede del af kognitionsteorien kan det således principielt fremhæves, at en stor del af den kognitive bearbejdning, som finder sted i forbindelse med receptionen af de illustrationsdominerede sofistikerede annoncer, er dirigeret af en proces, som virker "bottom up". På baggrund af illustrationens dominans aktiveres en forholdsvis uformidlet kropslig reaktion eller emotion. Når en mere sofistikeret billedreklame i receptionen udløser en forholdsvis direkte emotionel-kropslig reaktion, skyldes det, at illustrationen repræsenterer omverdenen mimetisk og derfor associeres med de emotioner, som normalt er knyttet til erfaringer med denne. ${ }^{20}$ Under receptionen af de mimetisk organiserede sofistikerede annoncer er der med andre ord tale om en mønstergenkendelse, som er styret af det umiddelbare input fra omverdenen. Ved termen "umiddelbar" forstås her en relativ uformidlet genkendelse, som ikke influeres specielt meget af forventninger, indlæring og kontekst, dvs. som kun i ringe grad er hængt op på kulturelle koder. ${ }^{21}$

Omvendt er en stor del af den bearbejdning, som udløses under receptionen af de tekstdomine- 
rede annoncer, styret af en proces, som virker "top down". Under receptionen af disse reklamebudskaber udløses således en kognitiv bearbejdning, som i overvejende grad organiseres i overensstemmelse med allerede etablerede forestillinger, som knytter an til social indlæring og kulturel erfaring. Også her er der tale om mønstergenkendelse. Men i dette tilfælde præges fortolkningen markant af konventionsbestemte forventninger. ${ }^{22}$

\section{Eksempel på en sammensat annonce} fra 1930'erne. Denne annonce er klart tekstdomineret. Det krever en rationel top down bearbejdning for at begribe dens betydning. Forstaelsen af annoncens representation af den sociale scene $i$ skotojsbutikken baserer sig dermed $i$ hoj grad på allerede indlarte forventninger og monstre omkring, hvad der $i$ bestemte kontekster er passende opforsel. Tenkningsprocessen er overvejende konceptbaseret og deduktiv. Bearbejdningen af annoncen indebarer dermed en tankningsproces, der laber fra det generelle til det specifikke. Der sluttes således fra den sociale 'lovmessighed', at der til bestemte skofarver også horer bestemte cremetyper, til at et brud med denne 'motiverede' relation medforer social udstødelse: "Er da ikke alt, som det burde vere? Nej! Grethe glemte at kobe Vibe-Hastrups Skocreme! Hun glemte, at til nye sko horer en god Creme, der nojagtig svarer til Fodtojets sarlige Farve [...]" Samtidig med den konceptbaserede og deduktive tankningsproces appellerer annoncen endvidere til komplekse emotioner: nemlig til skamfolelsen ved ikke at have renpudsede sko: "Hvorfor maaler Piccoloen hende med et haanligt blik? Hvorfor har hun selv et beklemt folelse $i$ kroppen.?". Annoncen appellerer dermed til emotioner, som er forankret $i$ den sociale sammenligning. Som helhed er det karakteristisk for periodens reklamer, at de bidrog aktivt til den sociale frygt.

Alsted \& Hartvig Larsens typologi har imidlertid den svaghed, at den i forlængelse af Barthes især har fokus på sprogsiden i kompositionen. Dermed overser den, hvilket betydningsfelt der har størst virkning i receptionsøjeblikket. Og det er et problem, når den simple og den sammensatte/ komplekse annoncetype skal skelnes fra hinanden. De simple annoncer er nemlig kendetegnet ved en høj grad af redundans i samspillet mellem tekst og billede. Derved bliver illustrationens information udslagsgivende for den igangsatte perception. De sammensatte/komplekse annoncer er derimod kendetegnet ved, at tekstsiden tilføjer væsentlig information, som uddyber det, billedet fremviser. ${ }^{23}$ I de sofistikerede annoncer mangler denne ekstra information imidlertid, således at modtageren må danne sig sine egne hypoteser om, hvad annoncens betydning er. Dette sker ved at relatere billedets information til andre mønstre end de konventionelle.

Den simple og den sofistikerede annoncetype virker således begge "bottom up": den simple ved at afbilde en genkendelig genstand fra (vare)verdenen og den sofistikerede ved mimetisk at afbilde noget fra modtagerens erfaringsverden, som dog ikke nødvendigvis er direkte forståelig ud fra modtagerens viden om reklamegenren som sådan. Og da ingen ekstra tekstlig information kan give et "top down" supplement til betydningsdannelsen, forløber kognitionen ad andre veje end via den blotte genkendelse eller via en logisk slutning. ${ }^{24}$

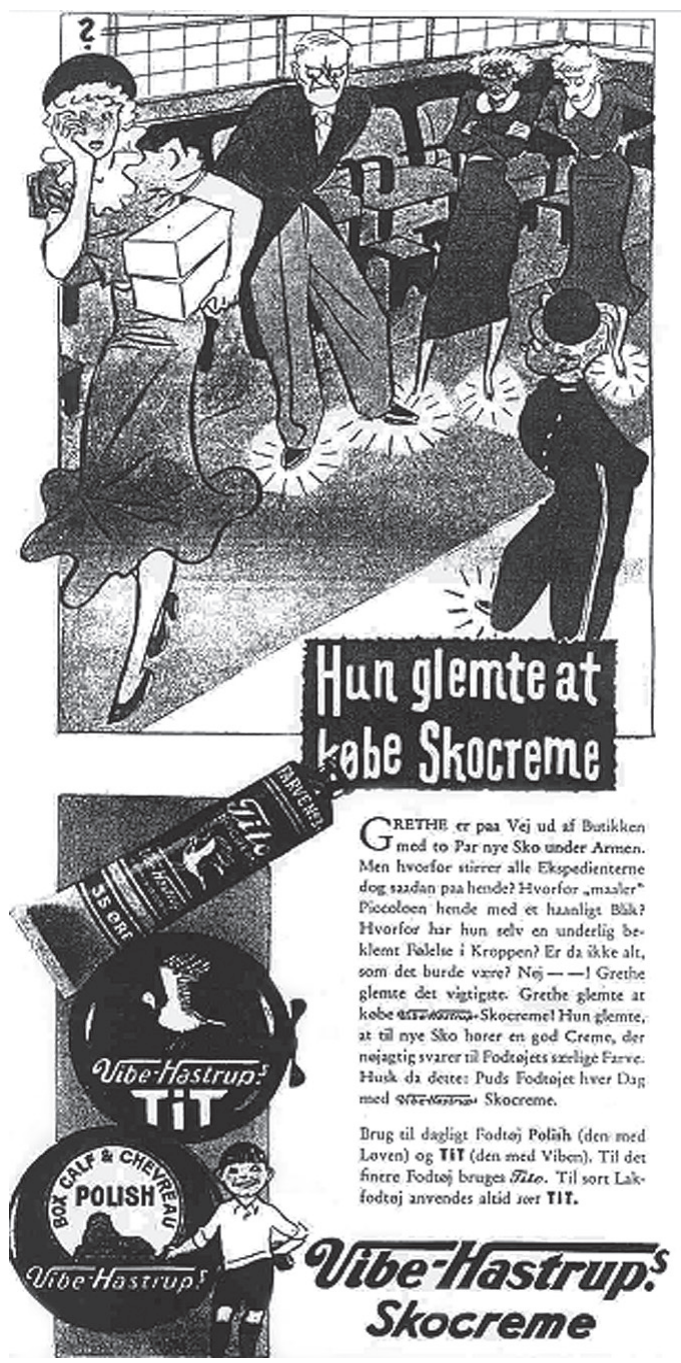




\section{Reklamens kategorier og den emotionelle proces}

Det ovenstående peger på et paradoks. Jo mere sofistikeret en billedreklame æstetisk set er, desto mere primitiv og emotionel-kropslig er den igangsatte kognition. Og omvendt: de relativt set mere enkle, tekstbaserede annoncer forudsætter en mere avanceret og rationel kognition.

Da emotionen i udgangspunktet knytter an til mimetisk-ikoniske forhold i omverdenen, kan billedreklamens illustrativt-ikoniske niveau i højere grad end dens tekstligt-symbolske niveau udløse krops-emotionelle reaktioner. Når den sofistikerede annoncetype i højere grad end den sammensatte type igangsætter en primitiv emotionel-kropslig kognition, skyldes det derfor, at dennes illustration relativt direkte forbindes med vores emotionelle indstilling i den virkelige verden. Omvendt vil den emotionelle kognition aftage i takt med, at annoncen bliver mindre sofistikeret og mere baseret på de tekstuelle betydningsfelter eller på konventionel genkendelighed.

Naturligvis kan annoncer, der er domineret af tekstlige organiseringer, også sagtens igangsætte emotionelle processer. Pointen er imidlertid, at den emotionelle proces i så fald har løsrevet sig fra sit mimetiske udgangspunkt i et 'her og nu'. I stedet er emotionen knyttet til en bearbejdnings$o g$ forfiningsproces, der indebærer en stadig større grad af rationalisering. Set fra et udviklingssemiotisk perspektiv er der dermed, for de tekstdominerede annoncetyper, tale om æstetiske kodninger, som er løsrevet fra den umiddelbare sansning og fra den emotion og bearbejdningsproces, som er forbundet hermed.

\section{Eksempel på en simpel tilbudsannonce.} Denne annonce er illustrationsdomineret. I udgangspunktet krever det en bottom up bearbejdning at begribe dens betydning. Der er tale om en meget velkendt representant for en bestemt produktkategori. Modsat den ligeledes illustrationsdominerede sofistikerede annoncekategori, som baserer sig på erfaringsverdenen som sådan, er der med den simple kategori imidlertid tale om en bearbejdningsproces, der er knyttet til en konventionel genkendelig genstand fra vareverdenen. Tankningsprocessen er dermed stereotypisk og induktiv. Annoncen appellerer hverken til primitive, grundlaggende eller komplekse, socialt distribuerede emotioner.

Blandt kognitionsteoretikere er der bred enighed om, at der eksisterer henholdsvis grund- læggende og komplekse emotioner. De grundlæggende emotioner er primært glæde, frygt, vrede, sorg, afsky, overraskelse og kærlighed. De komplekse emotioner er ærgrelse, misundelse, skadefryd, stolthed, taknemmelighed, skam, skyld og generthed. De komplekse emotioner adskiller sig fra de grundlæggende ved, at de i deres oprindelse ikke vedrører overlevelse eller biologisk baserede forhold som tilknytning og familiedannelse, men snarere social sammenligning (jf. Gade, 1998, s. 344). De grundlæggende emotioner er overvejende knyttet til ikonisk-mimetiske processer, mens komplekse emotioner i langt højere grad er knyttet til ikke-mimetiske processer: dvs. bundet op på sociokulturelle konventioner. Som allerede antydet i forbindelse med belysningen af "bottom up/top down"-processernes plads i reklamereceptionen, implicerer dette, at de illustrationsdominerede sofistikerede annoncer har en primitiv/universel emotionel kodning. Kognitionen hviler på genkendelsen af en almenmenneskelig følelse (se illustration 3). De tekstdominerede annoncer har derimod en rationel/social emotionel kodning, hvormed der refereres til kulturelle overbygninger på de helt primitive emotioner (se illustration 1). De illustrationsdominerede simple reklamer (f.eks. tilbudsannoncen), der afbilder en genstand, som kan genkendes i vareverdenen, udløser ingen eller kun ringe emotion (se illustration 2).

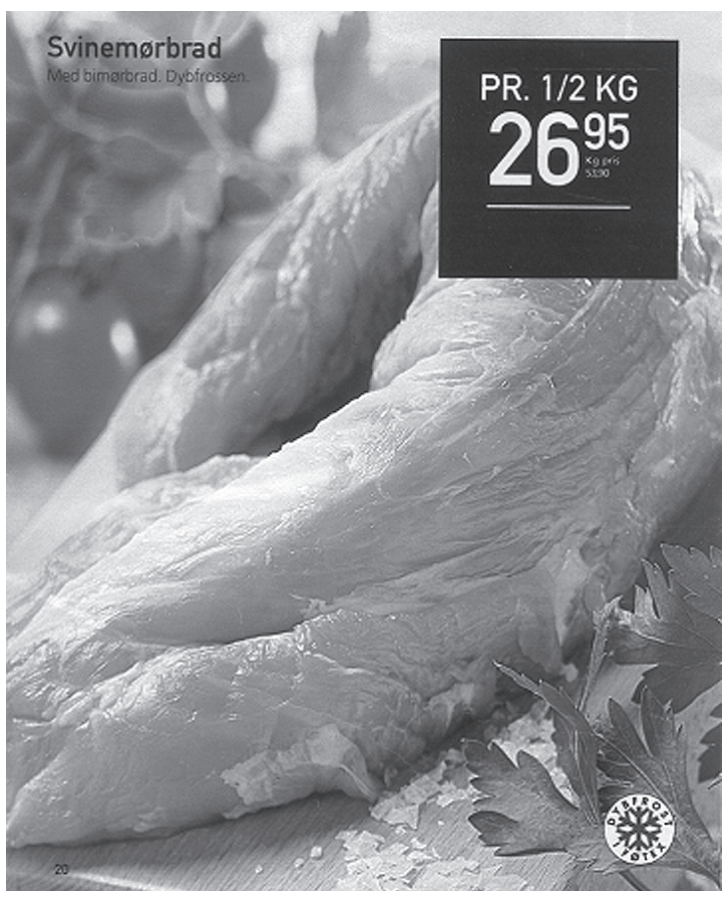




\section{Eksempel på en sofistikeret annonce fra} omkring 1990. Denne annonce er klart illustrationsdomineret. Illustrationen viser en familie samlet omkring en aids-doende $i$ sin sygeseng. Det involverer en primitiv bottom up bearbejdning at begribe dens betydning, idet scenen representerer en tabuiseret kontekst, hvortil der grundlaggende kun er knyttet ganske få eller slet ingen allerede etablerede monstre. Det kraver dermed en folelsesmassig involvering at bearbejde annoncens betydning. I denne perceptionsstyrede "bottom up"-proces appelleres der via bestemte kropsholdninger og ansigtsudtryk specielt til de grundlaggende folelser, ikke mindst sorgen. Der er således overvejende tale om en folelsesmessig bearbejdning, som er funderet $i$ biologisk og overlevelsesmassige forhold, og komplekse folelser, som er forankret $i$ den sociale sammenligning, er trådt $i$ baggrunden. Tenkningsprocessen er overvejende perceptionsbaseret og abduktiv. Da annoncen er kendetegnet ved, at der ikke er nogen tekst, der kan udpege og uddybe den visuelle information, er der grundlaggende tale om en åben og uafgjort kompositionsform. I den forstand kraver det abduktive slutninger, hois denne annonce skal forbindes med et produkt - eller med reklame i det hele taget.

Vi har således fundet tre kompositionstyper med hver deres emotionelle potentiale. Vi vil nu for- søge at vise, at der desuden knytter sig forskellige slutnings- eller inferensprocesser til disse typer.

\section{Tre astetiske grundorganiseringer}

Med udgangspunkt i filmens æstetik har kognitionsforskeren Peter Wuss plæderet for, at der eksisterer tre grundlæggende æstetisk-kompositoriske organiseringsformer: en perceptionsbaseret, en konceptbaseret og en stereotypibaseret organisering. ${ }^{25}$ Disse organiseringer foregår på forskellige bevidsthedsniveauer og udløser forskellige bearbejdningsprocesser i receptionen.

I forbindelse med den perceptionsbaserede organisering drejer det sig om, at recipienten via produktion af perceptuelle mønstre skaber sammenhæng i de visuelle stimuli. Denne produktion leder rent kognitivt til fremkomsten af topiske organiseringer. Ifølge Wuss dannes disse kun, hvis organiseringerne repeteres flere gange i det visuelle materiale. Organiseringer på dette niveau er således meget uafgjorte og ikke forlods forankret i kulturelle koder. Betydningsdannelsen foregår derfor forholdsvis "ubevidst", og det er i udgangs-

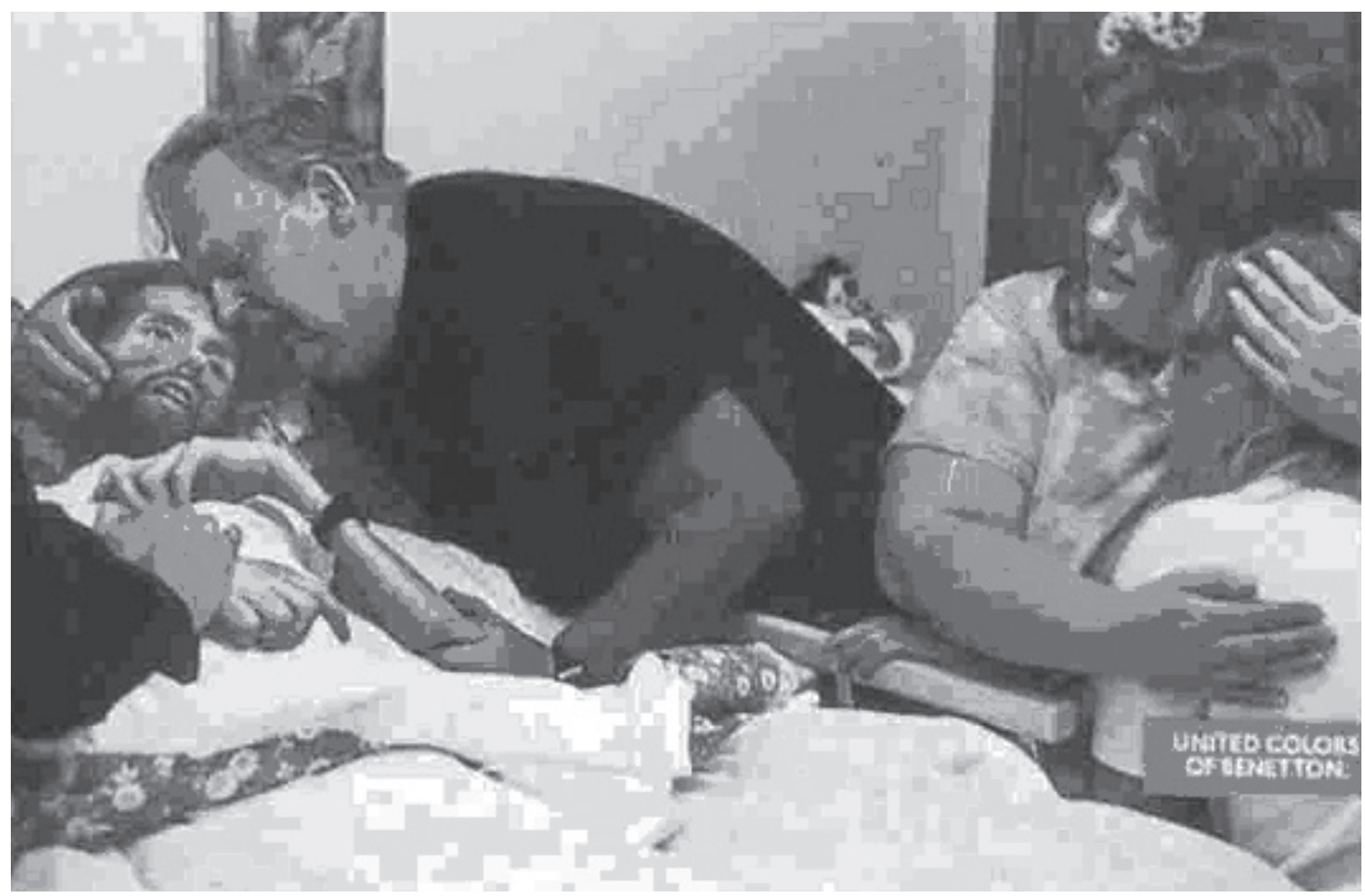


punktet svært for recipienten at skabe betydning af det, som perciperes. ${ }^{26}$ Hvad angår den konceptbaserede organisering, er der tale om, at recipienten noget lettere kan skabe sammenhæng i de visuelle stimuli. Ifølge Wuss skyldes dette, at den konceptbaserede organisering allerede er kognitivt repræsenteret hos recipienten. Således er organiseringer på dette niveau kun relativt uafgjorte, og betydningsdannelsen forløber derfor relativ bevidst. ${ }^{27}$ I forbindelse med den sidste af Wuss' organiseringer, den stereotypibaserede, er der tale om meget fastslåede organiseringer, som derfor på kort tid igangsætter en typisk og bestemt kognition hos recipienten. Der er m.a.o. tale om organiseringer og forbindelser, der allerede er indlærte. ${ }^{28}$

Disse tre organiseringsformer kan med fordel inddrages i belysningen af reklamekategoriernes kognitive kodning. Det giver god mening at hævde, at den sofistikerede kategori er domineret af en åben perceptionsbaseret organisering, at den sammensatte kategori er domineret af en forholdsvis lukket konceptbaseret organisering, mens den simple kategori er domineret af en helt lukket stereotypibaseret organisering. Rent æstetisk er den sofistikerede kategori nemlig kendetegnet ved, at betydningsdannelsen finder sted mellem overskrift og illustration, men med vægt på illustrationen. Og dette felt er ofte præget af en stor grad af åbenhed, så det kan være svært for recipienten at skabe sammenhæng i og mening af de visuelle stimuli (se illustration 2).

Receptionen af den sammensatte kategori er imidlertid allerede noget mere stabil. Fra Alsted \& Hartvig Larsens vinkel hænger dette nøje sammen med, at flere betydningsfelter er presente i den samlede komposition, samt at den konnotative og mytiske betydning er nedtonet. Tekstsiden for denne reklamekategori er med andre ord mere forklarende. Mentalt set har den en ret stabil repræsentation, som gør det lettere at skabe umiddelbar mening i det, der perciperes.

Den simple reklamekategori er lettest at afkode. Kompositorisk er den lukket og afgjort, og dette medvirker til at igangsætte meget velkendte mønstre og forestillinger i receptionen. Mentalt set er den stabilt repræsenteret, hvilket gør, at receptionens fortolkningsprocesser hurtigt når til vejs ende.

I det efterfølgende skal aspekter ved den kognitive bearbejdning, som igangsættes under receptionen af Wuss' tre æstetiske grundorganiseringer, skærpes ved at trække paralleller til den peirceanske semiotiks opfattelse af relationen mellem tegntype og tænkningsproces.

\section{Reklamekategorier, tegntyper og tænkningsprocesser}

Fra et peirceansk perspektiv forstås betydningsdannelse i udgangspunktet som en triadisk proces. Semiosis er den operation, der frembringer betydning ved at indstifte en gensidig forudsætningsrelation mellem repræsentamen, objekt og interpretant. Repræsentamen kan opfattes som det percipérbare tegn, et sanseindtryk, som repræsenterer noget andet. Dette andet er objektet, som dermed kan siges at være emnet for repræsentation (det som tegnet 'står for'). Det tredje korrelat, interpretanten, bestemmes af Peirce som tegnets significance or interpretation. ${ }^{29} \mathrm{I}$ den henseende er interpretanten det, som tyder, fortolker og forbinder repræsentamen med dets objekt.

Denne opfattelse af tegndannelsen som grundlæggende triadisk udgør en teoretisk og metodisk relevant nøgle til forståelsen af den tænkningsproces, som finder sted under receptionen af de respektive æstetiske grundorganiseringer, som kendetegner billedreklamens kategorier. Dels fordi Wuss' tre æstetiske grundorganiseringer med varierende dominans lader sig repræsentere ved tegntyperne ikon, indeks og symbol og altså således lader sig begribe inden for den anden trikotomis horisont. Og dels fordi disse tre tegntyper på sin side formelt lægger op til de kognitive inferensprocesser abduktion, deduktion og induktion, hvis fordeling på receptionen af de tre reklamekategorier dermed kan klarlægges.

Ifølge Peirce repræsenterer ikon, indeks og symbol tre væsensforskellige måder, hvorpå et tegn (repræsentamen) kan henvise til et objekt. Det ikoniske tegn ligner objektet med hensyn til kvalitetsmæssige sammenfald. Det indeksikalske tegn henviser til objektet i kraft af en fysisk nærhedsrelation. Mens det symbolske tegn refererer til objektet under hensyn til en kulturel konvention, vane eller forventning. Disse tre måder, hvorpå et tegn kan kobles med et objekt, kan ifølge Peirce forstås som tre forskellige principper, som tænkningen følger og bestemmes af. I artiklen "On a new list of Categories" (1867) anfører Peirce således, at i den abduktive tænkning er forholdet mellem præmisser og konklusion repræ- 
senteret ikonisk: de ligner i væsentlige henseender hinanden. I den deduktive tænkning er forholdet mellem præmisser og konklusion repræsenteret indeksikalsk: de står i en nærhedsrelation. Mens den induktive tænkning er karakteriseret ved, at forholdet mellem præmisser og konklusion er repræsenteret symbolsk: præmisserne repræsenterer konklusionen vanemæssigt. Denne karakteristik af relationen mellem reklamekategoriernes æstetiske grundorganiseringer, tegntype og tænkningsproces forekommer imidlertid noget abstrakt, hvorfor vi i det efterfølgende skal uddybe denne.

\section{Reklamekategoriernes kognitive kodning: de tre inferensprocesser}

For Peirce svarer abduktionen løst formuleret til en overraskende idé eller et gæt, som forbinder allerede kendte, men ikke før sammenknyttede erfaringer, og som derfor kan skabe ny erkendelse:

The abductive suggestion comes to us like a flash. It is an act of insight, although an extremely fallible insight. It is true that the elements of the hypothesis were in our minds before; but it is the idea of putting together what we have never before dreamed of putting together which flashes the new suggestion before our contemplation. ${ }^{30}$

Mere snævert formuleret analogiserer Peirce abduktionen med perceptionens funktionsmåde. Eller man kan sige, at abduktionen hos Peirce opfattes som en stiliseret beskrivelse af perceptionsprocessen:

[...] abductive inference shades into perceptual judgment without any sharp line of demarcation between them; or, in other words, our first premisses, the perceptual judgments are to be regarded as an extreme case of abductive inferences, from which they differ in being absolutely beyond criticism. ${ }^{31}$

Således tager abduktionen udgangspunkt i en perceptuel registrering, der angiver en mulighed mellem præmis og konklusion, og det er i den forstand, at der er tale om en tænkningsproces, som hviler på lighed og sammenfald mellem præmisser og konklusion. ${ }^{32}$ Man kan sige, at re- præsentamen er præmis, mens konklusionen er repræsenteret ved tegnets objekt i en tænkningsproces, der kommer i stand via ikonisk lighed.

Når Peirce taler om abduktion i forbindelse med perceptionens funktionsmåde, implicerer det endvidere, at visse momenter i den abduktive tænkningproces ligger uden for vores eksplicitte kontrol. ${ }^{33}$ Den del af den perceptuelle registrering og dom, som følger abduktionens mønster, udløses altså automatisk og "ubevidst". Anderledes formuleret kan det fremhæves, at i de rette omgivelser er perceptuel registrering noget "der sker med os", og ikke "noget vi gør". ${ }^{34}$ Det er interessant, i hvor høj grad de strukturelle forhold, som udløser en mere eller mindre omfattende abduktiv tænkningsproces, korresponderer med Wuss' perceptionsbaserede grundorganisering, som netop er kendetegnet ved en høj grad af perceptuel uafgjorthed. For at skabe et mønster i denne uafgjorthed forudsættes dannelsen af perceptuel invarians, som beror på lighedsproduktion mellem tilsyneladende adskilte områder, der dermed kan forbindes. De perceptionsorganiserede sofistikerede reklamekategorier har med andre ord en inhærent afkodningsstruktur, som overvejende udløser en abduktiv tænkningsproces i receptionen.

Den deduktive tænkningsproces er forankret i en generel regel, som sættes hypotetisk, og fra denne sluttes alle tænkelige enkeltkonsekvenser, som dermed med nødvendighed må være sande. Deduktionen kan således karakteriseres som en tænkningsproces, der virker "baglæns". Der er tale om en analytisk orienteret tænkning, hvis konklusioner dog kun har gyldighed i et tænkt univers, men dér følger konklusionerne også med nødvendighed.

Netop dette forhold, at tænkningsresultaterne følger med nødvendighed, er baggrunden for, at Peirce sammenstiller relationen mellem præmisser og konklusion med en indeksikalsk tegnrelation. Styrken ved den deduktivt og indeksikalsk dirigerede tænkning er altså dens effektivitet i fortolkningen af relativt genkendelige objekter og situationer. Der er tale om en overvejende "top down"-styret proces, hvor et i udgangspunktet rigt $\mathrm{og}$ åbent betydningsfelt erstattes af et simplere $\mathrm{og}$ mere lukket/afgjort. De strukturelle forhold, som udløser en indeksikalsk-deduktiv tænkningsproces, korresponderer med Wuss' konceptbaserede grundorganisering. Her har vi nemlig at gøre med en organisering, som kun indbefatter en relativ høj 
grad af perceptuel afgjorthed, og som hviler på kausal organisering. De konceptbaserede sammensatte reklamekategorier har med andre ord en inhærent afkodningsstruktur, som overvejende udløser en deduktiv tænkningsproces i receptionen.

I forbindelse med en bestemmelse af induktionens ars specifica løber man let ind i vanskeligheder, idet denne minder om abduktionen. Peirce noterer eksempelvis om sin egen behandling af processerne: "in almost everything I printed before the beginning of this century I more or less mixed up abduction and induction." ${ }^{35}$ Imidlertid er en relevant måde at holde tænkningsprocesserne ud fra hinanden, at placere dem indenfor en temporal horisont. Idet vi holder os in mente, at abduktionen kan forstås analogt til den før-lingvistiske perceptionsproces, giver det god mening at fremhæve, at tænkningsprocessen indledes med en abduktiv registrering, at deduktionen bearbejder og systematiserer den, mens induktionen afrunder den.

I et peirceansk perspektiv må induktionen betragtes som en evaluerende tænkningsform. Modsat deduktionen, der er analytisk specificerende, og som derfor kan udtale sig med nødvendighed inden for afgrænsede domæner, er induktionen en tænkningsproces, der hviler på en generalisering af det specifikke. Det er i et sådant lys, at Peirce betegner relationen mellem præmisser og konklusion i den induktive tænkning som en symbolsk relation, idet både symbolet og induktionen baserer sig på konvention, vane og velbegrundet forventning. Den symbolsk-induktive tænkningsproces svarer således til Wuss' stereotypibaserede organisering. Her har vi netop at gøre med en meget veletableret organisering, som bidrager markant til at producere normative forventninger i receptionen. De stereotypibaserede simple reklamekategorier har med andre ord en inhærent afkodningsstruktur, som overvejende udløser en induktiv tænkningsproces i receptionen.

Opsummerende kan det fremhæves, at den sofistikerede reklamekategori har en afkodningsstruktur, som indbyder til en aktivering af tænkningens primitive niveauer. Den sammensatte reklamekategori har en afkodningsstruktur, som udvikler disse niveauer. Mens den simple reklamekategori har en afkodningsstruktur, som indbyder til en lukning og afrunding af tænkningsprocessen. Videre kan det udledes, at alle tre tegntyper og alle tre tænkningsprocesser er aktive under den kognitive bearbejdning af konkrete billedreklamer. Men også at der i den kognitive bearbejdning af de respektive kategorier findes et klart dominansforhold mellem tegntype og tænkningsproces.

Vi har i det foregående kategoriseret annoncer i tre kompositionstyper og vist, hvorledes der til hver type svarer bestemte emotionelle og kognitive processer i receptionen. Vi vil nu afslutningsvis samle op på vores resultater og diskutere komposition og kognition i forhold til annoncers effekt.

\section{Kategori, kognition og kommunikationsmål}

Med udgangspunkt i et konkret eksempel fra Diesels meget omtalte annoncekampagne fra anden halvdel af 1990'erne har medieforskeren John Thorup (1999) sat spørgsmålstegn ved de meget sofistikerede annoncers evne til at kommunikere betydning til modtageren. Thorups undersøgelsesdesign er i al sin enkelhed oplagt, set inden for det lingvistiske paradigme. Han har på semiologisk grundlag nærlæst en reklame og derefter analyseret en række gymnasieelevers stile om samme annonce. Konklusionen er, at gymnasieelever i bedste fald kun har en delvis forståelse af annoncens righoldige betydningspotentiale. Dette resultat får Thorup til at problematisere rigtigheden af en af de populære forestillinger om den yngre generation. Undersøgelsen synes nemlig at vise, at de unge ikke er nær så kompetente, ironiske tekstlæsere, som det almindeligvis antages. Selvom Dieselkampagnen har stor popularitet i netop denne generation, er de unges faktiske forståelse af den begrænset.

Ud fra det ovenstående kan vi imidlertid sige, at Thorups undersøgelse hviler på en forkert præmis: nemlig den at betydningsdannelse udelukkende er knyttet til sproglig forarbejdning af budskabets information. Naivt antager han således, at billedet - det altdominerende betydningsfelt i Dieselannoncer - leses, og at den sproglige afrapportering af denne læseproces er udtømmende og pålidelig dokumentation for de tanker, overvejelser, fornemmelser og følelser, som præger receptionsprocessen. Den fremherskende bearbejdningsproces i denne type annoncer er en "bottom up", perceptionsstyret kognition. Men Thorup har behandlet denne kognition, som om den var "top down" og 
konceptbaseret. Ved at insistere på, at modtagernes betydningsdannelse kan afdækkes ved at analysere deres deduktive slutninger, miskender han, at de væsentlige slutninger i dette tilfælde er af abduktiv karakter.

Når vi opponerer mod det lingvistiske paradigme, skyldes det fremdeles, at det frembringer til tider interessante, men samtidig ofte fejldimensionerede resultater. Ved at prioritere annoncekompositionens sproglighed og ved at fokusere på de konceptbaserede kognitionsprocesser overses væsentlige aspekter ved både komposition og kognition. Desuden frembringer det lingvistiske paradigme indsigter, som kan være meget fjerne og indirekte i forhold til den reelle receptionssituation. Kun et fåtal mediebrugere skriver en stil efter at have set en reklame, for nu at tage Thorups eksempel. Reklamereceptionens realitet er tværtimod den, at mediebrugere eksponeres for mange, antageligt flere tusinde reklamer dagligt, og at der - ofte i bedste fald - således kun er splitsekunder af kognitiv opmærksomhed på den enkelte reklame. I dette meget korte øjeblik afgøres det, hvilken form for betydning og kognition det kan blive til. Den hidtidige reklamesemiotik har kun undtagelsesvis haft dette kommunikationsproblem for øje. Og det er måske den væsentlige grund til, at semiotikken ikke har fået en vedvarende plads i handelshøjskolernes reklameforskning.

Vores teorigennemgang har peget på tre typer af annoncekomposition med hver deres form for kognitiv bearbejdning. Det kan gengives i følgende skema:
De sofistikerede og simple kompositionstyper har det tilfælles, at de er baseret på illustrationen. Den væsentlige information findes i billedet. I den simple annonce, f.eks. tilbudsannoncen, er billedet imidlertid stereotypt genkendeligt som en konventionelt bestemt typisk repræsentant for en velkendt art. Billedets afkodning forløber nærmest per automatik og uden at implicere følelsesmæssige aspekter. Fælles for de sofistikerede og sammensatte annoncer er derimod, at de kan indebære følelsesmæssig bearbejdning. I de sammensatte annoncers tilfælde spilles der overvejende på sociale og således sekundære emotioner (se illustration 1). Og disse ekspliciteres i annonceteksten, som er det dominerende betydningsfelt.

Vores tese er følgende: disse tre kompositionstyper har på grund af forskellene i følelses- og tankemæssig bearbejdning hver deres styrke og svaghed i forhold til annoncers kommunikationsmål. Disse mål er at opnå opmærksomhed, forståelse og erindring.

De illustrationsbaserede annoncer vil typisk have nemt ved at opnå indledende opmærksomhed. Men på grund af stereotypien vil de simple annoncer kun svært kunne fastholde opmærksomheden, med mindre modtageren eksplicit opsøger annoncens eneste information (typisk prisen i tilbudsannoncen).

Den sofistikerede annonce vil kunne fastholde opmærksomheden, men vil - som Thorups undersøgelse til fulde viser - kunne udløse forståelsesproblemer. Dette skyldes fremdeles den abduktive tænkningsproces, som kan vanskeliggøre

\begin{tabular}{|l|l|l|l|l|l|}
\hline $\begin{array}{l}\text { Kompositions- } \\
\text { type }\end{array}$ & $\begin{array}{l}\text { Grundbe- } \\
\text { arbejdning }\end{array}$ & Emotion & Organisering & Tegntype & Inferens \\
\hline Sofistikeret & Bottom up & Grundlæggende & Perception & Ikon & Abduktion \\
\hline Sammensat & Top down & Kompleks & Koncept & Indeks & Deduktion \\
\hline Simpel & Bottom up & - & Stereotypi & Symbol & Induktion \\
\hline
\end{tabular}


begribelsen, uden at det dog behøver at hæmme erindringen. Når erindringsmålet nås, selvom forståelsesmålet ikke er indfriet, skyldes det måske netop de grundlæggende emotioner, som annoncen formår at aktivere (se illustration 2).

De tekstbaserede sammensatte annoncer er på grund af deres deduktive slutningsform i særdeleshed egnet til at fremme forståelsesmålet. Om erindringsmålet så efterfølgende nås afhænger ikke mindst af, om annoncetekstens argumentation på troværdig vis formår at vække sociale emotioner. Denne annoncetype har imidlertid problemer med det første mål: opmærksomheden. Den kan for det første let drukne i mængden af andre (reklame)budskaber og opnår derfor ingen indledende opmærksomhed. For det andet kan en fortsat opmærksomhed hæmmes af, at modtageren afstår fra at indgå i et analytisk, konceptbaseret samarbejde med budskabet. Han/hun "nægter" rollen som laser og insisterer i stedet på rollen som beskuer.

Forcen ved en peirceansk funderet reklamesemiotik er således, at æstetik, kognitiv bearbejdning og effekt kan forbindes på en mere præcis måde end hidtil. Semiologien har i bedste fald ret uformidlet teoretiseret over forholdet mellem æstetik og effekt (f.eks. Alsted \& Hartvig Larsen). Omvendt har forbrugeradfærdsteorien udarbejdet relationen mellem kognition og effekt uden at kunne forbinde den med æstetik. Vores artikel er i den henseende et indledende forsøg på at tilvejebringe en sådan forbindelse. ${ }^{36}$

\section{Perspektiv: kognition og receptionsforskning}

I flere bidrag har Schrøder plæderet for at genoverveje grundlaget for receptionsforskningen i medievidenskaben. Han har for det første talt for en ny syntese mellem kvalitative og kvantitative analyser i form af store kvalitative interviewundersøgelser (Schrøder 2000). Dette øger analysens repræsentativitet, og dermed også dens politiske og samfundsmæssige gennemslagskraft, gevaldigt. For det andet har han argumenteret for nødvendigheden af en mere finmasket model til analyse af kvalitative receptionsdata (Schrøder 2003). Hermed bliver det muligt at indfange de forskellige faktorer, der indvirker på modtagerens betydningsdannelse. Idet han betoner vigtigheden af at skelne forståelsen af budskabet fra aspekter som f.eks. relevans (motivation), genrekendskab (konstruktion), holdning og handling, fører Schrøders model til en vigtig nuancering af cultural studies traditionen i receptionsforskningen. Her har receptionsprocessens aspekter hidtil i høj grad været blandet sammen i det analytisk diffuse begreb "decoding" (Hall 1980). ${ }^{37}$

I vores bud på en peirceansk funderet reklamesemiotik er der en metodisk og teoretisk dimension, som er beslægtet med, men også forskellig fra Schrøders bestræbelse på at udvide receptionsforskningens metodiske arsenal og øge præcisionen af den analytiske terminologi. Vi tilslutter os til fulde Schrøders argumentation for en mere håndfast brug af andre metoder end kun det kvalitative interview. Men hvis receptionsforskning skal udvikle sig til en virkelig mangfoldig, multidimensional disciplin, så er en syntese med den kvantitative interviewmetode ikke fyldestgørende.

På den ene side bør receptionsforskningen genopdyrke en glemt side af sin fortid: nemlig inspirationen fra receptionsæstetikken (f.eks. Olsen \& Kelstrup 1981). Receptionsforskningens måde at tackle budskabets æstetik på er endnu meget rudimentær. I bund og grund er den nemlig - i tråd med cultural studies traditionen - baseret på en meget enkel, semantisk orienteret opfattelse af tekststrukturer: på den kulturalistiske aflægger af det lingvistiske paradigme. De tekstanalytiske undersøgelser af betydningens mikrostrukturer, som f.eks. Eco og Iser udmærker sig ved på det sproglige plan, bør dog suppleres med en egentlig visuel semiotik for at kunne beskrive kompositionens syntaktiske og pragmatiske dimensioner (f.eks. Messaris 1997, Saint-Martin 1990, Sonesson 1988).

På den anden side bør receptionsforskningen, i særdeleshed når det gælder undersøgelse af reklamer, orientere sig mod adfærdsvidenskabernes eksperimentelle metoder. Receptionsforskningens spørgeteknik er, hvor raffineret den ellers udvikles, bedst egnet til at analysere modtagernes forståelse, fortolkning, vurdering og holdning til teksten. Det der fortrinsvis undersøges er m.a.o. den konceptuelle organisering af receptionen: dvs. om og hvordan forståelsesmålet nås, og hvordan modtageren evaluerer budskabets mening. ${ }^{38}$ Når interviewmetoden virker mest optimalt, afdækker den budskabets relevans for modtagerens problemstillinger og hverdag. Men de perceptive aspekter ved receptionen, der er afgørende for, at 
modtageren i det hele taget bliver klar over budskabets eksistens, kan ikke analyseres med denne metode. Det er således mere oplagt at bruge laboratoriet, når opmærksomhed og erindring skal undersøges. ${ }^{39}$ Derfor bør receptionsforskningen begynde at inddrage de tidligere så forkætrede eksperimentelle designs som f.eks. erindringstests og eye tracking.

Receptionsforskningens pionerdage er forbi, som Schrøder siger (2000). Nu hvor denne forskning for længst er blevet en accepteret, endda mainstream del af medievidenskaben, er det måske på høj tid at genfinde noget af den tværfaglighed, som karakteriserede pionerdagene - dvs. til at videreudvikle det receptionsæstetiske spor og til at udfolde sammenhængen mellem reception og perception. I sidstnævnte forbindelse er det oplagt, at medievidenskabens store nybrud fra 1980'erne etablerer et platform til 1990'ernes store nybrud, kognitionsteorien. Det vil nemlig kunne give en både dybere og mere omfattende indsigt i receptionssituationen.

\section{Litteratur}

Alsted, C. (1989a). "Ungdomskultur, mad og reklamefilmstil”. In L. Højbjerg (red.) Reception af levende billeder. København.

Alsted, G (1989b). "Semiologi i den kvalitative prætest af reklamefilm”. In MedieKultur nr. 10.

Alsted, G. \& Larsen, H.H. (1991). "Toward a Semiotic Typology of Advertising Forms". In H. Hartvig Larsen et. al (red.) Marketing E' Semiotics. København.

Barthes, R. (1964). "Présentation". I: Communications no. 4.

Barthes, R. (1980). "Billedets retorik". In B. Fausing \& P. Larsen (eds.) Visuel Kommunikation. København.

Bordwell, D. (1985). Narration in Fiction Film. London.

Buhl, C. (1989). "Hvis det ikke kan kommunikeres, så er det ikke". In L. Højbjerg (red.) Reception af levende billeder. København.

Buhl, C. (1991). "The Consumer's Ad". In H. Hartvig Larsen et. al (red.) Marketing \& Semiotics, København.

Buhl, C. (2000). “Estetisk kommunikation i reklamer”. In F. Stjernfelt \& O. Thyssen (red.) Æstetisk kommunikation. København.

Dahl, H. \& Buhl, G. (1993). Marketing \& Semiotik. København.

Emmeche, C. (1990). "Kognition og omverden - om Jakob von Uexküll og hans bidrag til kognitionsforskningen". In Almen semiotik nr. 2. Århus.

Fish, S. (1980). Is There a Text in This Class?. Cambridge (Mass.)
Hidtil har receptionsforskningens cultural studies inspirerede hovedstrøm nemlig især udforsket receptionens situationelle kontekst: hvordan mediebudskabet lever i modtagerens meningsunivers, og hvorledes dette 'liv' er kulturspecifikt. I det ovenstående har vi på kognitionsteoretisk og semiotisk grundlag argumenteret for en anden, oftest overset, men fremdeles lige så væsentlig problemstilling: nemlig hvordan budskabet qua sin æstetiske komposition får betydning i receptionsøjeblikket. Vores interesse gælder altså ikke spørgsmålet om, hvordan budskabet lever videre efter eksponeringen, men hvordan det i det hele taget bliver synligt, relevant og mindeværdigt for modtageren. Denne virkning beror i vid udstrækning på almenmenneskelige evner til at sanse, føle og tænke - på universelle kompetencer.

En for alvor multidimensional receptionsforskning må således forholde sig både til budskabets mening og dets virkning, til kulturspecifikke såvel som universelle betydningsprocesser - ideelt set i en frugtbar sammentænkning af kultur og kognition.

Gade, A. (1998). Hjerneprocesser, kognition og neurovidenskab. København.

Grodal, T. K. (1993). Cognition, Emotion and Visual Fiction. København.

Hall, S. (1980). "Encoding/decoding". In S. Hall et al Culture, Media, Language. London

Hartvig Larsen, H. et al (red.) (1991). Marketing E Semiotics. København.

Jantzen, C. (1993). "Strictly for men”. In J.F. Jensen. (red) (1993): Reklame-Kultur. Aalborg Universitetsforlag.

Jensen, J. F. (red.) (1993). Reklame - Kultur. Aalborg Universitetsforlag.

Lakoff, G. (1987). Women, Fire and Dangerous Things. Chicago.

Larsen, P. (1980). "Reklame og retorik". In B. Fausing \& P. Larsen (red.) Visuel Kommunikation. København.

Larsen, P. (1988). "Musik og moderne billedfiktioner". In Kultur og Klasse nr. 60. København.

Lévi-Strauss, G. (1994). Den vilde tanke. (opr. udg. 1962). København.

Messaris, P. (1997). Visual Persuasion. The Role of Images in Advertising. Thousand Oaks.

Mick, D.G. \& C. Buhl (1992). "A meaning-based model of advertising experiences", In Journal of Consumer Research Vol. 19

Olsen, M. \& G. Kelstrup (red.) (1981). Vark og leser. København

Ottesen, O. (1985). Innforing i Markedskommunikation. København

Peirce, C. S. (1931-58). Collected Papers. Cambridge. Mass. 
Saint-Martin, F. (1990). Semiotics of Visual Language. Bloomington.

Schrøder, K. (2000). "Pionerdagene er forbi! - Hvor går receptionsforskningen hen?", In MedieKultur Nr. 31

Schrøder, K. (2003). "Generelle aspekter ved mediereception? - et bud på en multidimensional model for analyse af kvalitative receptionsinterviews". In MedieKultur nr. 25.

Sonesson, G. (1988). Pictorial Concepts. Lund.

Sonesson, G. (1992). Bildbetydelser. Inledning till bildsemiotiken som vetenskap. Lund.

Stigel, J. (2001). "TV advertising virtually speaking". In G. Agger \& J.F. Jensen (red.) The Aesthetics of Television. Aalborg.

Thorup, J (1999). "Hvor er den ironiske generation?”. In Mediekultur nr. 29.

Umiker-Sebeok, J (red.) (1987). Marketing Eீ Semiotics. Berlin.

Wuss, P. (1993). Filmanalyse und Psychologie. Strukturen des Films im Wahrnehmungsprozes. Berlin.

Østergaard, P. \& C. Jantzen (2000). "Shifting perspectives in consumer research: From buyer behaviour to consumption studies". In S.C. Beckmann \& R.H. Elliott (eds.) Interpretive Consumer Research. København.

\section{Noter}

1 For en kort oversigt over disse paradigmatiske skift se Østergaard \& Jantzen 2000.

2 Dette er internationalt markeret ved den toneangivende antologi af Umiker-Sebeok (ed.) 1987. På nationalt plan er Hartvig Larsen et al (eds.) 1991 en vigtig manifestation. Den lille lærebog Marketing og Semiotik af Dahl \& Buhl (1993) viser, at der var et behov for en pædagogisk fremstilling af feltet: reklame- og marketingsemiotikken så på det tidspunkt ud til at have fået definitivt fodfæste på uddannelserne.

3 Denne interesse kommer klarest til udtryk i Jensen et al (eds.) 1993.

4 For en interessant beskrivelse af semiotikkens vilkår på Handelshøjskolen København, se Buhl 2000.

5 Ved kulturalisme forstår vi den socialkonstruktivistiske antagelse, der opfatter betydningsdannelse som en kulturafhængig proces. Kulturalismen bygger på den relativistiske slutning, at betydningsforskelle bygger på kulturforskelle.

6 Jf. Barthes, 1964, s. 2. Dermed vender Barthes op og ned på Saussures rangorden, hvor lingvistikken 'blot' er en fagdisciplin under den almene semiotik. Denne omvending af relationen mellem lingvistik og semiotik kan kaldes lingvisticisme. Den gør sprogtegnet til model for tegnet overhovedet og analyserer således også andre udtrykformer som om, de var sproglige.

7 For en udførlig kritik af Barthes' brug af konnotationsbegrebet, se Sonesson 1992, s. 192ff.

8 Endda den danske Barthes-profet Peter Larsen (1988) synes at have øje for dette problem. I sit forsøg på at beskrive, hvad billedet evt. gør ved sproget, opretholder han dog - egentlig paradoksalt - Barthes' begrebspar.
9 Strukturalismens stræben efter universalisme og universalier er mest udfoldet $\mathrm{i}$ fonologien. I kulturvidenskaberne kommer den klarest til udtryk i den strukturelle antropologi, se f.eks. Lévi-Strauss 1994.

10 Et glimrende eksempel på denne tilgang er klassifikationen af tv-reklamers udsigelsesforhold, se f.eks. Stigel 2001.

11 Undtagelsen der bekræfter reglen er Messaris 1997.

12 For at gribe i egen barm så se f.eks. Jantzen 1993.

13 I Buhl $(1989,1991)$ er der tale om seks respondenter, i Mick \& Buhl (1992) er der tre respondenter.

14 Schrøder (2000, s. 78) mener i modsætning til os, at Buhls undersøgelser netop har høj validitet, fordi respondenternes udsagn "er udtryk for folks egen livsverden, for autentiske betydninger fremsat med folks egne ord, ikke noget som forskeren har påduttet folk gennem et spørgeskemas stive kategorier."

15 Alsted er tillige en af foregangsmændene i udviklingen af fokusgruppeinterviews $\mathrm{i}$ forbindelse med prætestning. For hans videnskabelige bidrag på dette område, se Alsted 1989a, 1989b.

16 Jf. også Emmecke 1990, s. 54.

17 Dette kognitive grundlag for reklamemodtagelse er i overensstemmelse med Grodals overvejelser over universelle træk ved mediereception (MedieKultur nr. 22, s. 17 (1994))

18 Det, som adskiller disse to typer af reklamer, er ifølge Alsted \& Hartvig Larsen, at illustrationen i den simple annonce kun viser produktet frem, mens den i den sammensatte annonce viser en typisk brugssituation.

19 I det følgende overtager vi med en vis beklagelse terminologien i Alsted \& Hartvig Larsens kategorisering. Vores brug af "simpel", "sammensat", "kompleks" og sofistikeret" skal således ikke forstås i et evolutionært eller valoriserende ærinde.

20 Jf. også Messaris op.cit. s. 57.

21 Bottom up bearbejdning (også kaldet data-organiseret bearbejdning) angiver en proces, der tager sit udgangspunkt i et simpelt input, som via efterfolgende interpretation udbygges. Begrebet dækker følgelig over en bearbejdningsmåde, som udelukkende fungerer $\mathrm{i}$ én retning, hvilket vil sige, at hvad der sker på et givet tidspunkt foregår uafhængigt af senere processering. Systemet er i sin funktion selvberoende og bearbejder dermed input på en sådan måde, at det ikke kan 'vende tilbage' og korrigere allerede etablerede mønstre.

22 Top down bearbejdning (også kaldet teori-organiserede eller konceptuelle processer) vedrører dermed en kognitiv bearbejdningsform, som er styret af forventninger, som er uddraget af tidligere erfaringer, baseret på konteksteffekter og allerede indlærte mønstre, og hvor der opbygges mere komplekse enheder, koncepter eller interpretationer. I modsætning til bottom up bearbejdningen er der tale om en bearbejdningsform, der kan korrigere allerede etablerede mønstre.

23 I det efterfølgende vil vi se bort fra den komplekse kategori, der ikke er særlig klart defineret hos Alsted \& Hartvig Larsen.

24 Det er denne alternative slutningsproces, som man i Barthes-traditionen har forsøgt at indfange vha. det lingvistiske begreb konnotation. Vi vil dog senere $\mathrm{i}$ 
denne artikel plædere for at anvende det peirceanske begreb abduktion i stedet.

25 Wuss 1993, s. 12.

26 ibid s. 58.

27 ibid s. 59.

28 ibid s. 60.

29 Jf. Peirce CP: 8.184

Jf. Peirce CP: 5.181

1 Jf. Peirce CP: 5.182

2 Jf. Peirce CP: 2.96

3 Jf. Peirce CP: 5.55

34 Peirce CP: 7.627

35 Jf. Peirce CP: 8.227

36 I det videre arbejde inden for det kognitive paradigme er det oplagt at udarbejde erindringsmålet meget mere, end vi her har gjort. Peirces tre inferenstyper kan nemlig via skemabegrebet forbindes med erindring/ hukommelse og med den læringsproces, som også er enhver reklames hensigt. Det er oplagt at relatere abduktion, deduktion og induktion til henholdsvis skemadannelse, skemaudbygning og skemabekræftelse. Derved bliver det tillige muligt at præcisere forholdet mellem information og æstetik: de forskellige kompositionstyper rummer forskellige former for information, der processeres i hver sin type slutningsproces og frembringer forskellige hukommelsesskemaer.

37 I Hall-traditionen bruges afkodningsbegrebet til indkredsning af tre mulige læsestrategier i forhold til den indkodede tekst: hhv. den dominerende, forhandlende og oppositionelle læsning. Disse strategier betegner de forskellige ideologiske måder, hvorpå modtageren kan relatere sig til tekstens ideologi på. I sidste ende er Halls hypotetiske model for reception funderet i klassestrukturen.

38 Det er da også grunden til, at især fokusgruppeinterviews har fået kommercielt fodfæste. I reklamebranchen f.eks. bruges kvalitative metoder i pretestning af budskabet for at indhente viden om, hvorledes modtagere vil bedømme reklamen.

39 Det paradoksale ved interviewmetoderne er fremdeles, at de ofte er betydeligt mindre realistiske med hensyn til perceptions- og kognitionsprocesserne end laboratoriets kunstige setting.

Christian Andersen er Ph. D.-studerende ved Institut for Kommunikation, AAU, og Christian Jantzen er lektor samme sted. 